\title{
In vitro anti-HIV activity of crude extracts from Tinospora cordifolia
}

\author{
Mamidala Estari", Lunavath Venkanna, Annem Srinivas Reddy \\ From First International Science Symposium on HIV and Infectious Diseases (HIV SCIENCE 2012) \\ Chennai, India. 20-22 January 2012
}

\section{Background}

Human immunodeficiency virus (HIV) infection causes acquired immune deficiency syndrome (AIDS) and is a global public health issue. Anti-HIV therapy involving chemical drugs has improved the life quality of HIV/ AIDS patients. However, emergence of HIV drug resistance, side effects and the necessity for long-term antiHIV treatment are the main reasons for failure of antiHIV therapy. Therefore, it is essential to isolate novel anti-HIV therapeutics from natural resources. The aim of the present study was to evaluate the invitro antiHIV activity of $T$. cordifolia plant extracts.

\section{Methods}

Extracts were prepared from dried leaves in n-hexane, dichloromethane, ethyl acetate and n-butanol. A toxicity study was performed on all crude extracts using peripheral mononuclear blood cells (PBMCs) isolated from whole blood. HIV-1 RT inhibition activity of the all solvent extracts of $T$. cardifolia was determined using a commercial kit.

\section{Results}

Among the tested extracts, the n-hexane and n-butanol crude extracts of $T$. cordifolia showed moderate cytotoxic activities against PBMCs with CC50 values ranging from $5.7-12.0 \mu \mathrm{g} / \mathrm{ml}$. In the HIV-1 reverse transcriptase assay $T$. cardifolia plant extracts showed good inhibitory activity, which was near that of the reference drug. Ethyl acetate extract shows 85 percentage of HIV-1 RT inhibition activity at a concentration of $20 \mathrm{mg} / \mathrm{ml}$.

\section{Conclusion}

The leaves of T. cardifolia extracts are shows anti-HIV 1 activity and this plant has great potential for developing useful drugs. Extraction of important biologically-active phytochemicals from this plant will certainly be helpful in protecting and treating various viral diseases in human beings.

Published: 4 May 2012

doi:10.1186/1471-2334-12-S1-P10

Cite this article as: Estari et al:: In vitro anti-HIV activity of crude extracts from Tinospora cordifolia. BMC Infectious Diseases 2012 12(Suppl 1):P10.

\footnotetext{
* Correspondence: estari08@gmail.com

Infectious Diseases Research Lab, Department of Zoology, Kakatiya University, Warangal, Andhra Pradesh, India
}

Submit your next manuscript to BioMed Central and take full advantage of:

- Convenient online submission

- Thorough peer review

- No space constraints or color figure charges

- Immediate publication on acceptance

- Inclusion in PubMed, CAS, Scopus and Google Scholar

- Research which is freely available for redistribution 